\title{
Identification the Factors Influencing Customer Satisfaction on Service Quality in Jamuna Bank
}

\author{
K. M. Salah Uddin*, Nymatul Jannat Nipa, Mamunur Rashid \\ Department of Management Information Systems, Faculty of Business Studies, University of Dhaka, Dhaka, Bangladesh
}

Email address:

salahuddin@du.ac.bd (K. M. S. Uddin),nipa@du.ac.bd (N. J. Nipa)

To cite this article:

K. M. Salah Uddin, Nymatul Jannat Nipa, Mamunur Rashid. Identification the Factors Influencing Customer Satisfaction on Service Quality in Jamuna Bank. International Journal of Business and Economics Research. Vol. 4, No. 2, 2015, pp. 30-35. doi: 10.11648/j.ijber.20150402.12

\begin{abstract}
The aim of this research was to examine the level of service quality as perceived by customers of Jamuna Bank Limited situated in Dhaka, Bangladesh. Literature tells us that if the banks are providing higher service quality then the customers are satisfied. Service quality measure is based on modified version of SERVQUAL as proposed by Parasuraman et al. (1988), which involve five dimensions of Service quality, namely Reliability, Responsiveness, Empathy, Assurance, and Tangible. One sample Z test analysis was employed to test the impact of service quality on customer satisfaction. The results of this study indicated that service quality is an important antecedent of customer satisfaction. It is apparent from the present study that banks in Bangladesh to seek and improve the elements of service quality that make the most significant factor of customer satisfaction.
\end{abstract}

Keywords: Customer Satisfaction, Service Quality, Jamuna Bank Limited, Bangladesh

\section{Introduction}

Achievement of high economic growth is the basic principle of present emerging economy. In achieving that objective, the banking sector plays an important role in Bangladesh. The enormous popularity of banking sector in this country is backed by billions of customers. Like other businesses, success of services provider is based upon on high quality relationship with customers (Panda, 2003). Customer satisfaction means when customer expectation matches performance of product or services (Soomro, Memon, Channa, 2012). In banking sector customer satisfaction is considered as a big challenge to maintain the customer loyalty through satisfied services. Banking sector is expanding its hand by different activities every day. At the same time the banking process is becoming faster, easier and the banking arena becoming wider. As the demand for the better service increase day by day, they are coming with different innovative ideas and products. In order to survive in the competitive field of the banking sector, all banking organizations are looking for better service opportunities to provide their fellow clients. It has found in different researches repeatedly that service quality influences organizational outcome such as performance superiority (Poretla \& Thanassoulis, 2005), increasing sales profit
(Levesque \& Mc. Dougal, 1996; Kish, 2000; Duncan \& Elliot, 2002) and market share (Fisher, 2001), improving customer relations, enhance corporate image and promote customer loyalty (Newman, 2001; Szymigin \& Carrigan, 2001; Caruana, 2002; Ehigie, 2006).

As a prominent bank in Bangladesh, Jamuna Bank Limited always ready to maintain the highest quality services by upgrading Banking technology prudence and applying high standard of business ethics through its established commitment and heritage. Today in the era of extreme competition Jamuna Bank Limited is considered customer satisfaction as the fundamental unit of success in the banking sector. They always try to be in the shape of long-run customer's attachment by showing their inner experiences about the values attainment from the services offered as like others renowned banks do.

\subsection{Statement of the Problem}

Customers are the key sources of any kind of business. To keep customer for a long period of time businesses have to make them satisfy. To measure customer satisfaction and service quality with the help of various dimension (tangible, empathy, assurance, responsiveness and reliability) in Moulvi 
Bazar Branch, Jamuna Bank Limited (JBL).

\subsection{Objective of the Study}

In banking sector, customer satisfaction is considered as a big challenge to maintain through different value added services. It is important because satisfied customers are ready to conduct banking transactions again and again with the same bank. The principal objective of our study is to identify customer satisfaction of Jamuna bank. We want to compare customer satisfaction and service quality with the help of several dimensions.

\section{Literature Review}

Customer Service is the set of behavior that a business undertakes during its interaction with its customers. It can also refer to a specific person or desk which is set up to provide general assistance to customers. In competitive environment, there is a need for banks to plan their strategies that will match with another. This can be achieved through the delivery of high service quality which will significantly lead to customer satisfaction and customer loyalty (Caruana et al., 2000; Caruana, 2002). Customer satisfaction has frequently been suggested to be the leading determinant of loyalty (Lam \& Burton, 2006). Service quality is the result of the comparison that customers make between their expectations about a service and their perception of the way the service has been performed (Lehtinen \& Lehtinen, 1982; Lewis \& Booms, 1983, Gronroos, 1984; Parasuraman et al., 1985; 1988; Caruana, 2002).

The present research employs SERVQUAL scale (Parasuraman et al., 1988) to measure the customers' satisfaction. Among general instruments, the most popular model used for evaluation of service quality is SERVQUAL, a well-known scale developed by Parasuraman et al. (1985, 1988). The attributes of (Parasuraman et al., 1985), were: tangibles, reliability, responsiveness, competency, courtesy, assurance, credibility, security, access, and understanding. Parasuraman et al. (1988) later reduced these ten dimensions into five by using a factor analysis. Based on the five dimensions, a 20-item survey instrument for measuring service quality has been developed. Five dimensions are-

Tangibles: Tangible property in law is, literally anything which can be touched and includes both real property and personal property (or moveable property) such as interior decoration, currencies, buildings, real estates, vehicles, inventories, equipments and precious metals.

Reliability: It means ability to perform the promised service accurately. If the client assumes that the company is not able to continue its service proper in the future they will not interested to banking with them. Time consciousness of employees, accurate services providing; less queue are the examples of reliability.

Responsiveness: Responsiveness as a concept of computer science refers to the specific ability of a system or functional unit to complete assigned tasks within a given time. Service times, sound computing facilities, availability of office assistance are the examples of responsiveness.

Assurance: It means the knowledge and ability of the employees to develop trust in the mind of the clients about the completion of the task properly and on time. Secured and quality banking services are the application of assurance.

Empathy: Empathy is the capacity to recognize and, to some extent, share feelings (such as sadness or happiness) that are being experienced by another sentient or semi-sentient being. To ensure better service it is very important for the employees to have empathy. Empathy means giving individual attention and taking extra care of the customer for example welcoming staff.

Perceived service quality is an attitude related to the superiority of the service, whereas satisfaction is related to a specific transaction (Parasuraman et al., 1985). Ehigie (2006) suggests that there is a significant positive relationship between customer satisfaction and customer loyalty/retention which is important for firms to make profit. Service quality plays effective role in banking sector so management should focus on customer satisfaction that enhance its productivity. Literature suggest that if any organization want to become a market leader then its management team should make strong bonding with customer. Vimi and Mohd (2008) found that customer satisfaction is linked with performance of banks after study of the determinants of performance in the Indian retail banking industry based on perception of customer satisfaction. According to Portela \& Thanassolis, (2006), not only the relationship between service quality and customer satisfaction in banking system are limited, but also the existing studies on bank branches efficiency is so much important. Service quality is of utmost importance in analyzing the performance of bank branches, since service quality is the reason for survival for any bank. Excellence in service quality is a key to achieve customer satisfaction which is the primary goal of business organizations, due to the advantages of customer retention (Ehigie, 2006).

The two separate terms "satisfaction" and "quality" are difficult to define in general, and press writers tend to use those terms interchangeably. Although these two consensuses share something in common, the fundamental causes and outcomes differ from one another. While satisfaction is a wide and broad concept in general, service quality has specific attributes of the service itself. Service quality is a reflection of the customer's perception of reliability, assurance, responsiveness, empathy and tangibles. Whereas customer satisfaction is more inclusive and perceived according to service quality, product quality, price, situational factors, personal factors and others.

The increasing awareness among customers about their rights, demands and highly competition requires constant progress in service quality from the bank for their customers (Kheng, Mahamad, Ramayah, 2010). The present research intends to test whether the bank customers are happy with the services provided to them, which mean customer satisfaction. Jamuna Bank Limited is also being chosen for this research as it better reflects the banking industry of Bangladesh. 


\section{Research Methodology}

In this paper the population consist the customers of Jamuna bank who visit Moulvi Bazar branch. The selection of respondents was based on non probability convenience sampling technique. As well as employees of the branches helped us a lot by giving their valuable opinions and knowledge. Primary information is under consideration by interviewing customers of Jamuna Bank mainly. The underlying model of SERVQUAL (Parasuraman et al., 1988) was used by this research to evaluate the impact of service quality on customer satisfaction in Jamuna Bank Limited.
Data was collected through 60 respondents who filled out questionnaires. The questionnaire consists of 20 questions across the five dimension of service quality (tangible, reliable, assurance, responsiveness and empathy). A five point Likert scale from strongly disagree to strongly agree was used in collection of data. Here it is considered as, highly satisfied score $=5$, satisfied score $=4$, Neutral score $=3$, dissatisfied score $=2$, highly dissatisfied score $=1$. The tools which deployed in this paper were descriptive and frequencies, standard deviation and means were calculated. One sample Z test was performed later to do further analysis. The details of sample are given below in the Table 3.1.

Table 3.1. Details of population and sampling.

\begin{tabular}{lllll}
\hline Customer & Young people & Middle Age & Old people & Total Individual Sample \\
\hline Man & 14 & 21 & 12 & 47 \\
Woman & 05 & 06 & 02 & 13 \\
Grand Total & & & & 60 \\
\hline
\end{tabular}

\subsection{Data Analysis Methodology}

The Primary data from the questionnaire survey is collected and sorted based on the highly satisfied, satisfied, Neutral, dissatisfied and highly dissatisfied. These data's are establish based on the sex and age of the people.

Table 3.2. Different satisfaction level between the samples.

\begin{tabular}{|c|c|c|c|c|c|}
\hline Satisfaction Level & Tangibility & Reliability & Responsiveness & Empathy & Assurance \\
\hline Highly Satisfied & 9 & 11 & 7 & 11 & 9 \\
\hline Satisfied & 25 & 30 & 31 & 25 & 32 \\
\hline Neutral & 12 & 13 & 15 & 10 & 10 \\
\hline Dissatisfied & 10 & 4 & 4 & 9 & 6 \\
\hline Highly Dissatisfied & 4 & 2 & 3 & 5 & 3 \\
\hline Sample Size & 60 & 60 & 60 & 60 & 60 \\
\hline
\end{tabular}

The frequency distribution of customer satisfaction on different parameters is shown in the Fig. 3.1.

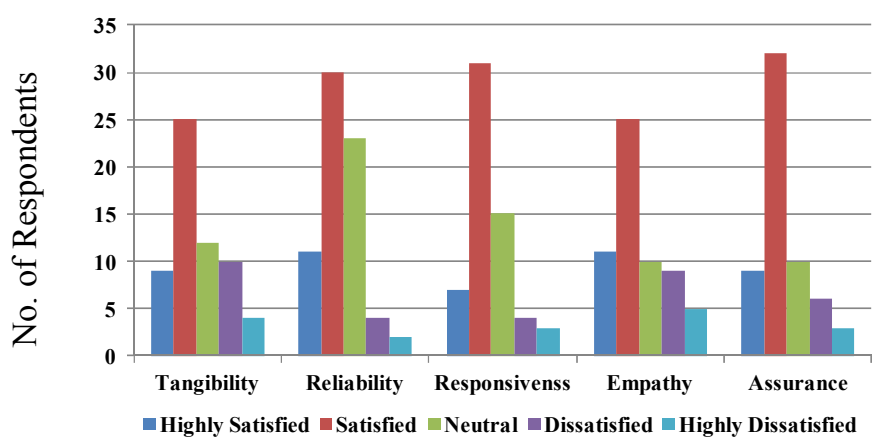

Fig. 3.1. Frequency Distribution of Customer Satisfaction.

\subsection{Data Analysis Based on Mean and Standard Deviation}

The mean is obtained dividing the sum of observed values by the number of observations, $(\mathrm{N})$. The standard deviation $(\sigma)$ measures the amount of variation or dispersion from the average. It is the square root of its variance. A low standard deviation indicates that the data points tend to be very close to the mean; a high standard deviation indicates that the data points are spread out over a large range of values.
Table 3.3. Comparison of Mean value \& Standard deviation between the samples.

\begin{tabular}{lll}
\hline Category of Satisfaction & Mean Value & Standard Deviation \\
\hline Tangibility & 3.41 & 1.13 \\
Reliability & 3.73 & 0.94 \\
Responsiveness & 3.58 & 0.95 \\
Empathy & 3.46 & 1.19 \\
Assurance & 3.63 & 1.01 \\
\hline
\end{tabular}

From the table we found mean of tangibility, reliability, responsiveness, empathy and assurance are $3.41,3.73,3.58$, 3.46 and 3.63 respectively. All mean values are considered satisfied for customers.

Standard deviation of tangibility, reliability, responsiveness, empathy and assurance are 1.13, 0.94, 0.95, 1.19 and 1.01 respectively.

Since the mean value is influenced by smallest value and the largest value. Therefore these data is not fully reliable. So it requires additional statistical test.

\section{Statistical Test for Jamuna Bank Limited}

Relationship between customer satisfaction and service quality can be found through statistical test. We are going to assume a hypothesis on the number of satisfied customers of 
JBL \& then perform $Z$ test on the samples to check whether the hypothesis is similar to the samples. In other words, whether the samples truly resemble the population and go with the hypothesis. So we are going to presume "every 9 out of 10 customers are satisfied then overall population is satisfied". In $\mathrm{Z}$ test we are going to use this hypothesis as our Null Hypothesis.

\subsection{One Sample Z Test Methodology}

A Z-test is any statistical test for which the distribution of the test statistic under the null hypothesis can be approximated by a normal distribution. Because of the central limit theorem, many test statistics are approximately normally distributed for large samples. For each significance level, the Z-test has a single critical value (for example: 1.96 for $5 \%$ two tailed) which makes it more convenient than the Student's t-test which has separate critical values for each sample size. Therefore, many statistical tests can be conveniently performed as approximate Z-tests if the sample size is large or the population variance known.

Step 1: Define Null \& Alternative hypothesis

Step 2: State $\alpha$ level (here $\alpha=0.05$ )

Step 3: State Decision Rule

As our $\alpha=0.05$ so in this case we are going to perform a two tail $\mathrm{Z}$ test.

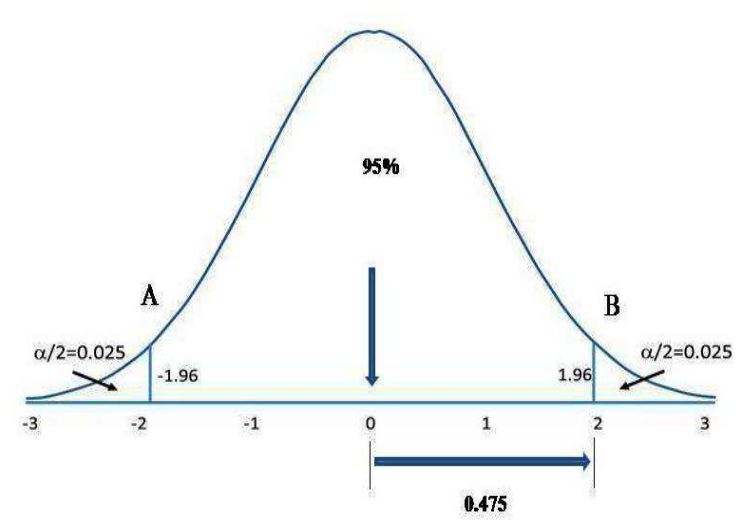

Fig. 4.1. Comparison between critical $Z$ value and standardized $Z$ value.

We are looking for the $5 \%$ amount of events that are least likely in the two tailed displayed in $2.5 \%$ on the right and $2.5 \%$ on the left. $95 \%$ is remaining in the middle. So if the $\mathrm{Z}$ that we calculate falls outside the $95 \%$ range we are going to conclude that it's a strange event and the samples are probably different so we are going to reject the null hypothesis.

We got to find out what value of $Z_{0}$ is associated with point A \& B in the graph. If we have $2.5 \%$ in one of the tails then we have $97.5 \%$ in the body. So using the table we got $Z_{0}=1.96$

If the $Z_{0}$ value resides in between +1.96 to -1.96 then we only accept the result otherwise we will reject the null hypothesis.

Decision Rule:

If $-1.96>Z_{0}>+1.96$, reject the null hypothesis

If $-1.96<Z_{0}<+1.96$, accept the null hypothesis
Step 4: Calculate Test Statistics,

$$
Z_{0}=\frac{\left(P-P_{0}\right)}{\sqrt{P_{0}\left(1-P_{0}\right) / N}}
$$

Where, $\mathrm{P}=$ sample Mean, $\mathrm{Po}=$ Hypothesis population mean, $\mathrm{N}=$ Total Sample Size.

Step 5: State the result

Step 6: state calculation, state whether the hypotheses claim is accurate or not.

Based on the questionnaire survey, those who marked as "highly satisfied", "satisfied" and "neutral" are accepted as "Overall satisfied". On the other hand rests are accumulated as "Overall dissatisfied"

\subsection{One Sample Z Test of Tangibility}

Table 4.1. Tangibility satisfaction level.

\begin{tabular}{lllll}
\hline \multicolumn{2}{l}{ Overall Satisfied } & & \multicolumn{2}{l}{ Overall Dissatisfied } \\
\hline $\begin{array}{l}\text { Highly } \\
\text { Satisfied }\end{array}$ & Satisfied & Neutral & Dissatisfied & $\begin{array}{l}\text { Highly } \\
\text { Dissatisfied }\end{array}$ \\
\hline 09 & 25 & 12 & 10 & 04 \\
\multicolumn{2}{l}{\begin{tabular}{l} 
Total Satisfied $=46$ \\
\hline
\end{tabular}}
\end{tabular}

Null Hypothesis: There is no significant difference between the sample proportion and the population proportion on tangibility dimension.

Therefore, null hypothesis $H_{0}: p=p_{0}$

Alternative Hypothesis: There is a significant difference between the sample proportion and the population proportion on tangibility dimension.

Therefore, alternative hypothesis $H_{a}: p \neq p_{0}$

Since, the standardized value $Z_{0}=-3.68$ falls outside the range of $-1.96<Z_{0}<+1.96$; therefore, the null hypothesis is rejected. i.e. the claim of $90 \%$ customers of JBL are overall satisfied is not true. From the test result we can say that the overall customers of Jamuna bank limited are dissatisfied on inside decoration of Jamuna Bank Ltd.

\subsection{One Sample Z Test of Reliability}

Table 4.2. Reliability satisfaction level.

\begin{tabular}{lllll}
\hline \multicolumn{2}{l}{ Overall Satisfied } & & \multicolumn{2}{l}{ Overall Dissatisfied } \\
\hline $\begin{array}{l}\text { Highly } \\
\text { Satisfied }\end{array}$ & Satisfied & Neutral & Dissatisfied & $\begin{array}{l}\text { Highly } \\
\text { Dissatisfied }\end{array}$ \\
\hline 11 & 30 & 13 & 04 & 02 \\
Overall Satisfied $=54$ & & Overall Dissatisfied $=06$ \\
\hline
\end{tabular}

Null Hypothesis: There is no significant difference between the sample proportion and the population proportion on reliability dimension.

Therefore, null hypothesis $H_{0}: p=p_{0}$

Alternative Hypothesis: There is a significant difference between the sample proportion and the population proportion on reliability dimension.

Therefore, alternative hypothesis $H_{a}: p \neq p_{0}$

Since, the standardized value of reliability $Z_{0}=-3.68$ 
falls outside the range of $-1.96<Z_{0}<+1.96$; therefore, the null hypothesis is accepted. i.e. the claim of $90 \%$ customers of JBL are overall satisfied is true. From the test result we can say that the overall customers are satisfied on accurate service, time conscious staff, less queue etc of Jamuna Bank Ltd.

\subsection{One Sample Z Test of Responsiveness}

Table 4.3. Responsiveness satisfaction level.

\begin{tabular}{lllll}
\hline \multicolumn{2}{l}{ Overall Satisfied } & & \multicolumn{2}{l}{ Overall Dissatisfied } \\
\hline $\begin{array}{l}\text { Highly } \\
\text { Satisfied }\end{array}$ & Satisfied & Neutral & Dissatisfied & $\begin{array}{l}\text { Highly } \\
\text { Dissatisfied }\end{array}$ \\
\hline 07 & 31 & 15 & 04 & 03 \\
Overall Satisfied $=53$ & & Overall Dissatisfied $=07$ \\
\hline
\end{tabular}

Null Hypothesis: There is no significant difference between the sample proportion and the population proportion on responsiveness dimension.

Therefore, null hypothesis $H_{0}: p=p_{0}$

Alternative Hypothesis: There is a significant difference between the sample proportion and the population proportion on responsiveness dimension.

Therefore, alternative hypothesis $H_{a}: p \neq p_{0}$

Since, the standardized value of responsiveness $Z_{0}=-0.52$ falls outside the range of $-1.96<Z_{0}<+1.96$; therefore, the null hypothesis is accepted. i.e. the claim of $90 \%$ customers of JBL are overall satisfied is true. From the test result we can say that the overall customers are satisfied on Service times, sound computing facilities, availability of office assistance of Jamuna Bank Ltd.

\subsection{One Sample Z Test of Empathy}

Table 4.4. Empathy satisfaction level.

\begin{tabular}{lllll}
\hline \multicolumn{2}{l}{ Overall Satisfied } & & \multicolumn{2}{l}{ Overall Dissatisfied } \\
\hline $\begin{array}{l}\text { Highly } \\
\text { Satisfied }\end{array}$ & Satisfied & Neutral & Dissatisfied & $\begin{array}{l}\text { Highly } \\
\text { Dissatisfied }\end{array}$ \\
\hline 11 & 25 & 10 & 09 & 05 \\
Overall Satisfied $=46$ & & Overall Dissatisfied $=14$ \\
\hline
\end{tabular}

Null Hypothesis: There is no significant difference between the sample proportion and the population proportion on empathy dimension.

Therefore, null hypothesis $H_{0}: p=p_{0}$

Alternative Hypothesis: There is a significant difference between the sample proportion and the population proportion on empathy dimension.

Therefore, alternative hypothesis $H_{a}: p \neq p_{0}$

Since, the standardized value $Z_{0}=-3.68$ falls outside the range of $-1.96<Z_{0}<+1.96$; therefore, the null hypothesis is rejected. i.e. the claim of $90 \%$ customers of JBL are overall satisfied is not true. From the test result we can say that the overall customers of Jamuna bank limited are dissatisfied on welcoming staff, behavior of employees of Jamuna Bank Ltd.

\subsection{One Sample Z Test of Assurance}

Null Hypothesis: There is no significant difference between the sample proportion and the population proportion on assurance dimension.

Table 4.5. Assurance satisfaction level.

\begin{tabular}{lllll}
\hline \multicolumn{2}{l}{ Overall Satisfied } & & \multicolumn{2}{l}{ Overall Dissatisfied } \\
\hline $\begin{array}{l}\text { Highly } \\
\text { Satisfied }\end{array}$ & Satisfied & Neutral & Dissatisfied & $\begin{array}{l}\text { Highly } \\
\text { Dissatisfied }\end{array}$ \\
\hline 09 & 32 & 10 & 06 & 03 \\
Overall Satisfied $=51$ & & Overall Dissatisfied $=09$ \\
\hline
\end{tabular}

Therefore, null hypothesis $H_{0}: p=p_{0}$

Alternative Hypothesis: There is a significant difference between the sample proportion and the population proportion on assurance dimension.

Therefore, alternative hypothesis $H_{a}: p \neq p_{0}$

Since, the standardized value of assurance $Z_{0}=-1.31$ falls outside the range of $-1.96<Z_{0}<+1.96$; therefore, the null hypothesis is accepted. i.e. the claim of $90 \%$ customers of JBL are overall satisfied is true. From the test result we can say that the overall customers are satisfied on secured and quality of services of Jamuna Bank Ltd.

\subsection{Data Analysis Summary}

By analyzing the above $\mathrm{Z}$ test result of the 5 samples we can come up to some decision as follows:

The Null hypothesis i.e. 9 out of 10 customers of JBL is satisfied with the banking service according to the $\mathrm{Z}$ test result of sample Reliability, Responsiveness \& Assurance.

The Null hypothesis i.e. 9 out of 10 customers of JBL is dissatisfied with the banking service according to the $\mathrm{Z}$ test result of sample Tangibility \& Empathy.

\section{Conclusion}

There is no doubt that customer satisfaction on service quality is a multi dimensional subject. Customer satisfaction is influenced by a lot of different parameters. The result of the study indicates that customers are satisfied with Jamuna bank limited although there was a little variation on their opinion. It is quite obvious from the research that the customer requirements are not fully met and they are very dissatisfied with some of the aspects of the bank (By modernizing the physical facilities \& equipments, employees training, personalize caring, implementing minor charges on service etc.). Again the research revealed that only two third of customers were more or less satisfied with the services of the bank and many of the respondents were on the neutral side of satisfaction line. JBL should attract these respondents and bring them to the positive side of the road so that strong relationship with the customers can be maintained. In order to retain competitive edge, investment in technology is always a top outline and under constant focus. Keeping the network within a reasonable limit, JBL strategy is to serve the customers through capacity building across multi delivery channels. They are better placed and poised to take customers through fast changing times and enable them compete more effectively in the market they operate. 


\section{References}

[1] Caruana, A. (2002). The effects of service quality and the mediating role of customer satisfaction. European Journal of Marketing, 36(7/8), 811-828.

[2] Caruana, A., Money, A.H. and Berthon, P.R. (2000). Service quality and satisfaction- the moderating role of value. European Journal of Marketing, 34(11/12), 1338-1352.

[3] Duncan, E., and Elliot, G. (2002). Customer service quality and financial performance among Australian retail financial institutions. Journal of Financial Services Marketing, 7(1), $25-41$.

[4] Ehigie, B. O. (2006). Correlates of customer loyalty to their bank: a case study in Nigeria. International Journal of Bank Marketing, 24(7), 494-508.

[5] Fisher, A. (2001). Winning the battle for customers. Journal of Financial Services Marketing, 6(2), 77-83.

[6] Gronroos, C. (1984). A service quality model and its marketing implications. European Journal of Marketing, 18(4), 36-44.

[7] Kish, J. (2000). Before your customers leave. Bank Marketing, $32(2)$, and 30 .

[8] Kheng, mahamad, Ramayah (2010). The Impact of Service Quality on Customer Loyalty: A Study of Banks in Penang, Malaysia. International Journal of Marketing Studies Vol. 2, No. 2; November 2010.

[9] Lam, R., and Burton, S. (2006). SME banking loyalty (and disloyalty): a qualitative study in Hong Kong.International Journal of Bank Marketing, 24(1), 37-52.

[10] Lehtinen, U., and Lehtinen, J.R. (1982). Service quality- a study of dimensions. unpublished working paper,Service Management Institute, Helsinki, 439-460.
[11] Levesque, T.J., and McDougall, G.H.G. (1996). Determinants of customer satisfaction in retail banking. International Journal of Bank Marketing, 14(7), 12-20.

[12] Lewis, R.C., and Booms, B.H. (1983). The marketing aspects of service quality. Emerging Perspectives in Service Marketing, in Berry, L.L., Shostack, G. and Upah, G. (Eds) American Marketing Association, Chicago, IL 99-107.

[13] Newman, K. (2001). Interrogating SERVQUAL: a critical assessment of service quality measurement in a high street retail bank. International Journal of Bank Marketing, 19(3), 126-139.

[14] Panda, T. K. (2003). Creating customer lifetime value through effective CRM in financial services industry. Journal of Services Research, 2(2), 157-171.

[15] Parasuraman, A., Zeithaml, V.A., and Berry, L.L. (1985). A conceptual model of service quality and its implications for future research. Journal of Marketing, 49, fall.

[16] Parasuraman, A., Zeithaml, V.A. and Berry, L.L. (1988). SERVQUAL: a multiple-item scale for measuring consumer perceptions of service quality. Journal of Retailing, 64(1), spring.

[17] Portela, M.C.A.S., and Thanassoulis, E. (2005). Profitability of a sample of Portuguese bank branches and its decomposition into technical and locative components. European Journal of Operational Research, 162(3), 850-866.

[18] Soomro, Memon, Channa (2012), Role of Customer Satisfaction and Service Quality in Public and Private Banks. Impact Factor 3.582 Case Studies Journal ISSN (2305-509X) Volume 3, Issue 6. http://www.casestudiesjournal.com Page 33.

[19] Szymigin, I., and Carrigan, M. (2001). Wherefore customer loyalty? Journal of Financial Services Marketing, 6(2), 6-8.

[20] Vimi, J. and Mohd, K.K. (2008), Determinants of performance in retail banking: perspectives of customer satisfaction and relationship marketing, Singapore Management Review, December. 